\title{
Production of nursing care in primary health care services ${ }^{1}$
}

\author{
Silvia Matumoto ${ }^{2}$ \\ Kátia Cristina dos Santos Vieira ${ }^{3}$ \\ Maria José Bistafa Pereira ${ }^{4}$ \\ Claudia Benedita dos Santos ${ }^{4}$ \\ Cinira Magali Fortuna ${ }^{2}$ \\ Silvana Martins Mishima ${ }^{5}$
}

This descriptive and quantitative study aimed to characterize the production of nursing care in primary health care services in a region of the city of Ribeirão Preto, state of São Paulo, Brazil. The study sample comprised care actions delivered by nurses and registered in the HygiaWeb Information System, from 2006 to 2009. Statistical analysis was performed. Results showed that nursing care delivered by nurses accounted for 9.5 to $14.6 \%$ of total professional care provided by professionals. Eventual care actions were the most frequent. The concentration of programmatic care was higher for children, women, pregnant and postpartum women. In conclusion, the predominance of eventual care demonstrated that the health system has been focused on acute conditions. Little of nursing work has been directed at the achievement of comprehensiveness, considering the inexpressive share of longitudinal follow up in total care delivery. The expansion of nursing staff represents potential for care delivery to the population, but further qualification of nursing actions is needed.

Descriptors: Primary Care Nursing; Health Services; Primary Health Care; Information Systems.

\footnotetext{
${ }^{1}$ Supported by Fundação de Amparo à Pesquisa do Estado de São Paulo (FAPESP), process \# 2008/00498-1.

2 PhD, Professor, Escola de Enfermagem de Ribeirão Preto, Universidade de São Paulo, WHO Collaborating Centre for Nursing Research Development, Brazil.

${ }^{3}$ RN, Student of Specialization Course, Universidade Federal de São Carlos, Brazil.

${ }^{4}$ PhD, Associate Professor, Escola de Enfermagem de Ribeirão Preto, Universidade de São Paulo, WHO Collaborating Centre for Nursing Research Development, Brazil.

${ }^{5}$ PhD, Full Professor, Escola de Enfermagem de Ribeirão Preto, Universidade de São Paulo, WHO Collaborating Centre for Nursing Research Development, Brazil.
} 


\section{Produção de atendimentos de enfermeiros em unidades da rede básica de saúde}

Objetivou-se caracterizar a produção de atendimentos, realizados por enfermeiros, em unidades da rede de atenção básica de um distrito no município de Ribeirão Preto, SP, Brasil. Trata-se de estudo quantitativo descritivo, cuja população de estudo constituiu-se pelos enfermeiros em atendimento, registrados no Sistema de Informação HygiaWeb, no período de 2006 a 2009. Realizou-se análise estatística. Os resultados mostraram que os atendimentos realizados pelos enfermeiros representaram entre 9,5 e 14,6\% do total de atendimentos dos profissionais. Aqueles do tipo eventual foram os mais realizados. Os programáticos tiveram maior concentração para crianças, mulheres, gestantes e puérperas. Concluiu-se que o predomínio de atendimento eventual demonstrou que o sistema de saúde esteve voltado para as condições agudas. Os enfermeiros pouco direcionaram seu trabalho para efetivar a integralidade diante dos inexpressivos atendimentos que caracterizam o acompanhamento longitudinal. A ampliação do quadro de enfermeiros representou potencial de oferta de atendimentos, mas observou-se necessidade de qualificação das ações de Enfermagem.

Descritores: Enfermagem de Atenção Primária; Serviços de Saúde; Atenção Primária à Saúde; Sistemas de Informação.

\section{Producción de atención prestada por enfermeros de la red primaria de salud}

Este estudio cuantitativo y descriptivo objetivó caracterizar la producción de atención prestada por enfermeros en servicios de la red primaria de salud de un distrito de Ribeirão Preto, provincia de São Paulo, Brasil. La muestra del estudio fue la atención de enfermeros registrada en el Sistema de Información HygiaWeb, en el período de 2006 a 2009. Se realizó análisis estadístico. Los resultados mostraron que la atención realizada por los enfermeros representó del 9,5 al 14,6\% del total de atención realizada por los profesionales. La atención del tipo eventual fue la más realizada. La atención programática tuvo mayor concentración para niños, mujeres, embarazadas y puérperas. Se concluye que el predominio de la atención eventual demostró que el sistema de salud estuvo enfocado en las condiciones agudas. Los enfermeros tienen direccionado poco su trabajo para lograr la integralidad tiendo en vista inexpresivas asistencias que caracterizan la atención longitudinal. La expansión del personal de enfermería representó potencial de mayor prestación de atención a la población, pero se observó la necesidad de la calificación de acciones de enfermería.

Descriptores: Enfermería de Atención Primaria; Servicios de Salud; Atención Primaria de Salud; Sistemas de Información.

\section{Introduction}

The assumption of primary health care as the organizing axis of the health system represents a challenge for cities in the implementation process of the Unified Health System (SUS), in view of conflicting interests and distinct understandings on how to organize and manage the health system(1) and the proposal to put the user at the center of the health care process ${ }^{(2)}$. Ribeirão Preto-SP is one of the Brazilian cities that assumed this commitment( ${ }^{(3)}$.

The implementation of the SUS furthered the expansion of the health service network, through a quantitative and diversified growth in the care offered 
at all levels and the improvement of municipal health management ${ }^{(4-5)}$.

In nursing, the increase of nursing staff in the Ribeirão Preto primary care network stands out, from seven nurses in 1987 to 172 in 1997, and reaching 232 in 2007 . This represents a $33.14 \%$ growth in comparison with the period before the implementation of the SUS(4).

Nurses' work process in primary health care has also gone through changes, not only in the quantitative sense, but also guided by SUS principles, with the family health strategy as a preponderant factor ${ }^{(5-6)}$. For primary care nurses, individual and collective care demands are enhanced, besides traditional management actions. In the 1980's and 1990's, their work was focused on the organization and maintenance of health services' infrastructure, whose predominant production referred to individual medical emergency care ${ }^{(7)}$. Specific nursing action were related to the organization of nursing team work and some collective health actions, such as vaccination and epidemiological surveillance $(4,7)$.

The strategies, mainly family health, as well as the community health agents, have allowed nurses to deliver nursing care aimed at users' health needs(8). In this sense, relevant initiatives have taken place to organize nurses' work, like that in the city of Curitiba, aimed at qualifying child and women's health care ${ }^{(6)}$.

The overlapping of management and care activities, however, has been appointed in scientific literature as a characteristic of nurses' work process, related to the production of subjectivity and suffering at work ${ }^{(9-10)}$.

A study about nurses' practice at primary health care units in a city in Rio Grande do Sul documented the following activities: management actions - nursing work coordination, organization, training and control and individual and collective health care, characterized by a focus on priority groups according to biological risk, disease or chronological groups for the organization of care $^{(11)}$.

A transition movement is observed in which nurses' activities during the nursing consultation predominantly focuses on the individual, without considering other factors involved in the health-disease process and the psychosocial context(12), reproducing physicians' work model(13). Also, movements of change are registered in the way health is produced, when nurses focus on comprehensiveness ${ }^{(14)}$ or on subjects' complexity(10).

The above aspects gave rise to a study on nurses' clinical practice in primary health care, with a view to characterizing this practice, analyzing its contribution to the qualification of care delivery and seeking ways to expand and qualify it.
In this paper, partial data are presented about nurses' care production in the primary health care network. The questions that guided the study were: Have nurses delivered clinical care to users? What is the share of nursing care in total primary health care production?

\section{Aim}

To characterize nursing care production at primary health care network units in Ribeirão Preto-SP.

\section{Method}

This descriptive and quantitative research focused on care delivery by nurses in the primary health care network, as registered in the Ribeirão Preto Municipal Health Secretary's (SMS-RP) information system, between 2006 and 2009.

Workers register care production in a computer system called Hygia, set up in 1996, which interconnects all primary health care network units. In 2007, the system was changed to an online system via WEB, and became known as HygiaWeb.

The SMS-RP provided secondary data in an Excel worksheet. This information referred to nurses' care delivery at the health units, according to the professional's code; care code; total care per type, professional and month, as well as data about care delivery per professional category to contextualize nurses' production in comparison with other workers.

The study considered units in the Western District, one of the five health districts in the city, with an estimated population of 141,998 inhabitants for $2009^{(3)}$. The district was selected because it has worked in partnership with a university for a long period in the city; it comprises 18 health units, including one district primary health care unit (UBDS), 4 traditional primary health care units (UBS-TRAD), 5 primary health care units with the Community Health Agent Strategy (UBSEACS), 1 Family Health Unit (USF), 7 Family Health Centers (NSF), 2 of which are managed by SMS-RP and 5 by the University of São Paulo.

At the above units, during the study period, 46 nurses were active in direct care, 13 at the UBDS and 33 at the USF/NSF, UBS-EACS and UBS-TRAD. The nurses in the Family Health and Community Health Agent teams worked 40 hours/week and the remainder was hired to work 20, 30 or 40 hours/week.

Care production was analyzed for the UBS that included data into the SMS-RP information system. In 
2006 and 2007, the data came from eight units. In 2008 and 2009, the analysis comprised 11 units, the eight from the previous biennium and three others. No data were included on care production at the UBDS, as this unit differs from the others because it offers specialized care and a 24-hour emergency service. The five NSF managed by the University were not included, as they do not register care data in the city's information system.

To register care and procedures, a code list is available, including 86 items any health work can use. Some codes had to be grouped for the sake of data analysis.

The Excel data the SMS-RP provided were exported to Statistical Package for Social Sciences (SPSS) software, version 16.0 for Windows, for the sake of exploratory analysis.

Approval for the research project was obtained from the Research Ethics Committee at the University of São Paulo at Ribeirão Preto College of Nursing - EERPUSP, protocol 0832/2007, in compliance with National Health Council Resolution 196/96.

\section{Results}

To contextualize nurses' care production in the primary health care network in the Western District of Ribeirão Preto, general care production was analyzed according to professional category.

Table 1 - Distribution of care delivery at primary health care units according to professional category. Western District, Ribeirão Preto-SP, Brazil, 2006 - 2009

\begin{tabular}{|c|c|c|c|c|c|c|c|c|}
\hline \multirow{3}{*}{ Categoria profissional } & \multicolumn{8}{|c|}{ Care delivery } \\
\hline & \multicolumn{2}{|c|}{2006} & \multicolumn{2}{|c|}{2007} & \multicolumn{2}{|c|}{2008} & \multicolumn{2}{|c|}{2009} \\
\hline & No. & $\%$ & No. & $\%$ & No. & $\%$ & No. & $\%$ \\
\hline Physician & 132479 & 60.7 & 130112 & 63.2 & 134839 & 52.5 & 151347 & 44.5 \\
\hline Secondary-Level Nursing Professional & 38457 & 17.6 & 30554 & 14.8 & 57717 & 22.5 & 120422 & 35.4 \\
\hline Nurse & 20803 & 9.5 & 24176 & 11.7 & 37576 & 14.6 & 45719 & 13.4 \\
\hline Dentist & 25124 & 11.5 & 20424 & 9.9 & 26179 & 10.2 & 22265 & 6.5 \\
\hline Others & 1337 & 0.6 & 613 & 0.3 & 504 & 0.2 & 582 & 0.2 \\
\hline Total & 218200 & 100 & 205879 & 100 & 256815 & 100 & 340335 & 100 \\
\hline
\end{tabular}

Table 1 shows that medical care is the main type offered to primary health care network users, ranging from $63.2 \%$ (2007) to $44.5 \%$ (2009) of all care delivered at the units under analysis. The production of secondary-level nursing workers ranged from $14.8 \%$ in 2007 to $35.4 \%$ in 2009. Nurses' care varied from $14.6 \%$ in 2008 to $9.5 \%$ in 2006 . Nursing tam care (sum of nurses and secondary-level nursing workers' care delivery) represented $27.1 \% ; 26.5 \% ; 37.1 \%$ and $48.8 \%$ in 2006, 2007, 2008 and 2009, respectively. Dental care production dropped from $11.5 \%$ to $6.5 \%$, and care by workers in other professional categories (pharmacists, psychologists, nutritionists and occupational therapists) remained below $1 \%$.

In the initial analysis, in the universe of 86 items, it was detected that nurses used 55 different code types, although some of these do not characterize as typical nursing care. Similar codes were grouped, like child care for example, which includes six codes: PR childcare, RP - childcare return appointment, CP - new childcare case, RF - child return appointment, EP - early stimulation and $\mathrm{PZ}$ - neonatal screening. The latter takes place during the infant's first nursing consultation at the UBS and may also represent a new childcare case.

Some codes were not included in any group: occasional, new case, return appointment, welcoming, diabetic care, hypertensive care, dressing and group care.

At the end of the grouping, 15 care code types were obtained for nurses' care delivery, whose distribution according to care type, health units and year is presented in Table 2. 
Table 2 - Percentage distribution of nurses' care according to care type and health units for 2006-2009 in the Western District of Ribeirão Preto-SP, Brazil

\begin{tabular}{|c|c|c|c|c|c|c|c|c|c|c|c|c|}
\hline \multirow{2}{*}{ Care Type } & \multicolumn{4}{|c|}{ USF/NSF } & \multicolumn{4}{|c|}{ EACS } & \multicolumn{4}{|c|}{ Traditional } \\
\hline & 2006 & 2007 & 2008 & 2009 & 2006 & 2007 & 2008 & 2009 & 2006 & 2007 & 2008 & 2009 \\
\hline Occasional & 78.0 & 84.1 & 81.8 & 83.5 & 91.5 & 93.0 & 55.0 & 24.7 & 96.1 & 95.9 & 78.2 & 67.7 \\
\hline Return & 9.3 & 6.7 & 1.8 & 5.8 & 0 & 0 & 0.1 & 0.1 & 2.4 & 0 & 0.6 & 0.3 \\
\hline New case & 7.1 & 5.5 & 0.7 & 2.6 & 0 & 0 & 0 & 0 & 0 & 0 & 0.5 & 0 \\
\hline Welcoming & 0.7 & 0 & 1.3 & 4.6 & 0 & 0 & 30.3 & 57.4 & 0 & 0 & 2.2 & 2.1 \\
\hline Child care & 1.8 & 1.3 & 0.8 & 2.0 & 0.3 & 0.9 & 2.4 & 2.6 & 0.5 & 2.7 & 3.2 & 3.6 \\
\hline School and adolescent care & 0.6 & 0.5 & 0 & 0 & 0 & 0 & 0 & 0.1 & 0 & 0 & 0 & 2.6 \\
\hline Women's care & 0.1 & 0.6 & 0.5 & 0.9 & 2.8 & 2.4 & 3.6 & 5.8 & 0.9 & 1.1 & 9.6 & 16.6 \\
\hline $\begin{array}{l}\text { Pregnant and puerperal } \\
\text { women's care }\end{array}$ & 0.8 & 0.3 & 0.1 & 0.1 & 1.9 & 0.7 & 1.2 & 1.1 & 0 & 0.1 & 2.7 & 4.4 \\
\hline SAH care & 0 & 0.2 & 0.2 & 0.1 & 0.1 & 0.1 & 0.2 & 0 & 0 & 0 & 0 & 0 \\
\hline DM care & 0 & 0.1 & 0.1 & 0 & 0.1 & 0.1 & 0.3 & 0.2 & 0 & 0 & 0 & 0 \\
\hline Care for tests & 1.6 & 0.7 & 0.1 & 0.1 & 0 & 0 & 0.1 & 2.7 & 0 & 0 & 0 & 0 \\
\hline Home care & 0 & 0 & 0.7 & 0.2 & 2.2 & 1.2 & 2.7 & 3.4 & 0 & 0.2 & 0.3 & 0.2 \\
\hline Group care & 0 & 0 & 0 & 0.1 & 0 & 0 & 0.1 & 0.4 & 0 & 0 & 1.0 & 2.1 \\
\hline Dressing & 0 & 0 & 0 & 0 & 0 & 0 & 0.3 & 0.9 & 0 & 0 & 0.3 & 0.4 \\
\hline Others & 0 & 0 & 11.9 & 0 & 1.1 & 1.5 & 3.8 & 0.7 & 0 & 0 & 1.3 & 0 \\
\hline Total & 100 & 100 & 100 & 100 & 100 & 100 & 100 & 100 & 100 & 100 & 100 & 100 \\
\hline
\end{tabular}

The health units were grouped according to the care design offered to the population: units with Family Health Strategy (USF/NSF), UBS with Community Health Agent strategy (UBS-EACS) and traditional UBS (UBSTRAD).

The predominant care type nurses deliver at the different types of health units during the study period is occasional care, although percentages in 2008 and 2009 correspond to $55 \%$ and $24.7 \%$ at the UBS-EACS and $78.2 \%$ and $67.7 \%$ at the UBS-TRAD. When adding Welcoming care, however, which reached $30.0 \%$ in 2008 and $57.4 \%$ in 2009 at the UBS-EACS and $2.2 \%$ and $2.1 \%$ in 2008 and 2009, respectively, at the UBS-TRAD, this results in the levels between $70 \%$ and more than $90 \%$ registered in the other years and at the other units analyzed.

The counterpart of the mainly occasional care is called programmed care, which reached the highest level at the UBS-TRAD in 2009 , i.e. $32.3 \%$ of care delivered in that year.

New cases and return appointments reach the highest percentage at the USF/NSF, while practically any care is observed at the other UBS-ECAS and UBS-TRAD.

Child care is highlighted in 2009, with $2.0 \% ; 2.6 \%$ and $3.6 \%$ of care delivered at the USF/NSF, UBS-EACS and UBS-TRAD, respectively.

The sum of care delivery to women, pregnant and puerperal women in 2009, according to the care model, corresponded to 1.0 (USF/NSF); $6.9 \%$ (UBS-EACS) and $21.0 \%$ (UBS-TRAD).
Percentages of care delivery to users with chronic illnesses, especially arterial hypertension and diabetes, were very low.

At the UBS-EACS, home, group and dressing care stands out in 2008 and 2009. In the category "Others", the figures observed in Table 2 mainly derive from care for which no code was specified.

At the UBS-TRAD, besides occasional care, child and women's care are observed. At the USF/NSF, besides occasional care, the nurses focused on care delivery that points towards longitudinal monitoring, like New cases and Return appointments, as well as child and women's care. Nurses at the UBS-EACS demonstrate a less discrepant distribution of programmed activities, despite the predominance of occasional non-programmed and welcoming activities.

\section{Discussion}

The distribution of care delivery by the set of workers at the primary health care units whose data were analyzed shows that the care model centered on medical care still persists ${ }^{(2)}$.

The nursing team's care production is highlighted, including nurses and secondary-level workers, in which nurses' production corresponded to $9.5 \%, 11.7 \%$, $14.6 \%$ and $13.4 \%$, respectively, in 2006, 2007, 2008 and 2009 of all care different workers delivered in the primary health care network. The data demonstrate the nurse category's participation in population health care in the District analyzed. 
The existence of different codes to identify similar care or the same risk group may arouse doubts when distinguishing the care type in the records. Thus, our analysis appoints the need to review the coding used at the SMS-RP, with a view to facilitating care records, avoiding errors, mistaken interpretation and insufficient or no registration.

The documentation of care delivery permits qualifying user care management. The use of information technologies to put in practice and document user care can facilitate nurses' care work in the primary health care network, but needs investments( ${ }^{(6)}$.

The fact that the nurses mainly deliver occasional care demonstrates that the emergency care model is maintained, in which work focuses on the immediate and palliative resolution of complaints. A difference is observed, however, in comparison with nurses' work in the 1980's and 1990's, who assumed the health service organization, so that physicians' work could take place within the emergency care perspective ${ }^{(4,7)}$. Nowadays, nurses themselves deliver clinical care during occasional nursing consultations, but without using the initial contact to schedule users' subsequent monitoring and trigger new nursing care production modes.

As the problems arriving in the primary health care network are chronic conditions, which need longitudinal follow-up to reach the solution expected at this care level(15), nurses are a professional group that can play a preponderant role in coping with this health problem ${ }^{(16)}$.

The results, however, show nurses' little participation in the monitoring of arterial hypertension and diabetes patients. This problem needs further analysis and is confirmed by findings from a study developed in cities in the State of Santa Catarina, registering the inefficiency of arterial hypertension actions at services working with the Family Health Strategy ${ }^{(17)}$.

The lack of alignment between the nature of the population's health problems and health service organization is the responsibility of all, managers, health professionals, educational institutions (including faculty members and students) and the population using the SuS ${ }^{(2)}$. Hence, one single category alone cannot be held responsible. Nevertheless, it should be appointed that nursing, as a social practice consolidated through action and interaction with other practices in the health area and society as a whole, has also been participating in the maintenance of the hegemonic way in which health units function ${ }^{(18)}$.

The results also demonstrated the weakness of the city's commitment to primary health care and the need to maintain the federal government's stimulating policies to strengthen primary health care.

The data arouse questions on nurses' participation in welcoming, their understanding of this care type and what should be registered under this code.

It should be highlighted that welcoming is aimed at identifying users' problems and needs, redirecting them inside the unit and externally with a view to greater agility and solution of users' demands. These dynamics would further the expansion and diversification of programmed care delivery for all professionals, including nurses, for the sake of user follow-up. In addition, it should be taken into account that welcoming is a process, and not an act, which the entire health team is responsible for $^{(10)}$, an aspect that cannot be further explored in this methodological design.

Based on the percentages below expectations for new cases and returns, as well as programmed care delivery to children, women, pregnant and puerpera women, hypertensive and diabetic patients, and the almost complete lack of records on group care, dressing and home care, it can be inferred that the welcoming performed was limited to occasional nursing consultations.

This situation of disequilibrium between occasional and programmed care goes against the National Primary Health Care Policy ${ }^{(19)}$, which refers to putting in practice the integration between programmed actions and spontaneous demands.

At the different health units, higher percentages are observed for care delivery to children, women, pregnant and puerperal women, signs that may be related to the implementation of care protocols for this population, such as Projeto Nascer, Floresce uma Vida and other care protocols for women with suspected pregnancy, initial consultation for pregnant women, family welcoming and pap smear test collection by the nurse. The emphasis on nursing work in these two population groups was also observed in another city that implemented the International Classification of Collective Health Nursing Practices in nursing consultations for children and women ${ }^{(20)}$. Other studies show nursing work focused on children, women, adults and elderly people(5,11).

Although the SMS-RP has a protocol for care delivery to hypertensive and diabetic patients in primary health care, nurses have not focused on this public.

The city's commitments expressed in the Pacto pela Vida (Pact for Life) ${ }^{(21)}$ should be reminded, which sets national priorities, including child, women's and elderly health actions, among others. These cover a significant part of arterial hypertension and diabetes patients. 
Data on home and group care delivery were surprising. At units working with the Family Health Strategy, actions like home visits and health education to groups for the sake of health promotions were almost absent. Percentages for these care types are low at the UBS-TRAD and UBS-EACS.

The fact that they did not perform group education activities aroused frustration in nurses, as this is related with the non-compliance of the Family Health Strategy's mission. The nurses attribute the non-accomplishment of group activities to the fact that most of their time is spent on nursing consultations and management actions $^{(9)}$.

Home visits by nurses dropped by $51 \%$ between 1999 and 2005 in an interior city in the State of Minas Gerais, while visits by other team members increased, also justified by the accomplishment of management

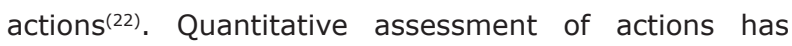
its limits. Therefore, it is important to add qualitative aspects. Thus, the way home visits take place may not mean rupture with the medical model but, instead, may reinforce it as curative practice ${ }^{(23-24)}$.

Let us return to the information systems nurses are expected to feed in daily work, and which are not articulated, enhancing insufficient registration. To give an example, both the Primary Health Care Information System (SIAB) and the HygiaWeb demand the completion of group activities, home visits and other types of care delivery by health workers. Despite the percentages, it cannot be affirmed that nurses at the USF/NSF and UBSEACS did not deliver this care, as no records may have been made, or in one of the information systems only. For the sake of clarification, nurses' care production registered in SIAB for the same period was not analyzed.

This confirms the need to make different information systems compatible, with a view to avoiding duplicate records and work overload and make information production more dynamics, enhancing its use in planning and health decision making(20).

\section{Conclusions}

Although the care records referred to some of the units in the health district studied, these indicate that nurses' contribution to the population's health care increased and is changing. One aspect that limited this study was the use of secondary data, the lack of records on care production in the municipal information system for some units in the district and the non-inclusion of the analysis of nurses' care coverage in the population of that area.
The predominance of occasional care appointed that the care design of the health system focuses on care delivery to acute conditions.

In this context, little of nurses' work has been directed at the primary health care principles, that is, putting in practice comprehensive care and developing bonding with the adjoined population, as longitudinal monitoring does not take place. This hampers the development of care actions with users and coaccountability for problem solving.

The quantitative increase in the SMS-RP's nursing staff represents the category's potential to offer health care to the population, but data reveal the need for managers to invest in the nursing area with a view to qualifying care delivery, as well as to review care delivery records.

\section{References}

1. Organização Pan-Americana da Saúde. Renovação da Atenção Primária em Saúde nas Américas: Documento de posicionamento da Organização Pan-Americana da Saúde/Organização Mundial da Saúde (OPAS/ OMS). Washington, D.C: OPAS, 2007. [acesso 24 ago 2010]. Disponível em: http://www.parlatore.com.br/ centrocolaborador/images/online/arquivo_renovacao_ atencao_primaria_Saude_americas.pdf

2. Costa GD, Cotta RMM, Ferreira MLSM, Reis JR, Franceschini SCC. Saúde da família: desafios no processo de reorientação do modelo assistencial. Rev Bras Enferm. 2009;62(1):113-8.

3. Secretaria Municipal da Saúde de Ribeirão Preto (BR). Plano Municipal de Saúde. Período 2010-2013. Ribeirão Preto: Secretaria Municipal da Saúde; 2009. [acesso 1 nov 2010]. Disponível em: http://www. ribeiraopreto.sp.gov.br/ssaude/vigilancia/planeja/pmsrp-2010-2013.pdf

4. Mishima SM, Almeida MCP, Matumoto S, Pinto IC, Oba MDV, Pereira MJB, et al. A classificação Internacional para a prática de enfermagem em saúde coletiva no Brasil - CIPESC - Apresentando o cenário de pesquisa do município de Ribeirão Preto. In: Chianca TCM, Antunes MJM. A classificação Internacional das Práticas de Enfermagem em Saúde Coletiva - CIPESC. Brasília (DF): ABEn; 1999. p. 204-41. (Série didática; Enfermagem no SUS).

5. Silva EM, Nozawa MR, Silva JC, Carmona SAMLD. Práticas das enfermeiras e políticas de saúde pública em Campinas, São Paulo, Brasil. Cad Saúde Pública. 2001;17(4):989-98. 
6. Silva SHS, Cubas MR, Fedalto MA, Silva SR, Lima TCC. Estudo avaliativo da consulta de enfermagem na rede básica de Curitiba-PR. Rev Esc Enferm USP. 2010;44(1):68-75.

7. Almeida MCP, Mello DF, Neves LAS. O trabalho de enfermagem e sua articulação com o processo de trabalho em saúde coletiva - rede básica de saúde em Ribeirão Preto. Rev Bras Enferm. 1991;44(2-3):64-75.

8. Peduzzi M. A inserção do enfermeiro na equipe de saúde da família, na perspectiva da promoção da saúde. I Seminário Estadual: O Enfermeiro no Programa de Saúde da Família; 09-11 novembro 2000; São Paulo, São Paulo. São Paulo: Anais; 2000. p. 1-11.

9. Feliciano KVO, Kovacs MH, Sarinho SW. Superposição de atribuições e autonomia técnica entre enfermeiros da estratégia saúde da família. Rev Saúde Pública. 2010;44(3):520-7.

10. Matumoto S, Mishima SM, Fortuna CM, Pereira MJB, Almeida MCP. Preparing the care relationship: a welcoming tool in health units. Rev. Latino-Am. Enfermagem. 2009;17(6):1001-8.

11. Nauderer TM, Lima MADS. Nurses' pratices at health basic units in a city in the South of Brazil. Rev. LatinoAm. Enfermagem 2008;16(5):889-94.

12. Maciel, I.C.F.; Araujo, T.L. Consulta de enfermagem: análise das ações junto a programas de hipertensão arterial, em Fortaleza. Rev. Latino-Am. Enfermagem. 2003;11(2):207-14.

13. Peña YF, Almeida MCP, Duranza RLC. O processo de trabalho do enfermeiro no cuidado à criança sadia em uma instituição da seguridade social do México. Rev. Latino-Am. Enfermagem. 2006;14(5):651-7.

14. Santos SMR, Jesus MCP; Amaral AMM, Costa DMN, Arcanjo RA. A consulta de enfermagem no contexto da atenção básica de saúde, Juiz de Fora, Minas Gerais. Texto Contexto-Enferm. 2008;17(1):124-30.

15. Cunha EM, Giovanella L. Longitudinalidade/ continuidade do cuidado: identificando dimensões e variáveis para a avaliação da Atenção Primária no contexto do sistema público de saúde brasileiro. Ciênc Saúde Coletiva. [periódico na Internet]. [acesso 17 mar 2012]. Disponível em: http://www.scielosp. org/scielo.php?script=sci_arttext\&pid=S141381232011000700036\&lng=en. http://dx.doi. org/10.1590/S1413-81232011000700036.

16. Halcomb EJ, Davidson PM, Salamonson Y, Ollerton R, Griffiths R. Nurses in Australian general practice: implications for chronic disease management. J Clin Nurs. 2008 Mar;17(5A):6-15.
17. Rabetti AC, Freitas SFT. Avaliação das ações em hipertensão arterial sistêmica na atenção básica. Rev Saúde Pública. 2011;45(2):258-68.

18. Rocha SMM, Almeida MCP. O processo de trabalho da enfermagem em saúde coletiva e a interdisciplinaridade. Rev. Latino-Am. Enfermagem. 2000;8(6):96-101.

19. Ministério da Saúde (BR). Portaria $n^{\circ} 648$, de 28 de março de 2006. Aprova a Política Nacional de Atenção Básica, estabelecendo a revisão de diretrizes e normas para a organização da Atenção Básica para o Programa Saúde da Família (PSF) e o Programa Agentes Comunitários de Saúde (PACS). Brasília; 2006. 59 p.

20. Silva AS, Laprega MR. Avaliação crítica do Sistema de Informação da Atenção Básica (SIAB) e de sua implantação na região de Ribeirão Preto, São Paulo, Brasil. Cad Saúde Pública. 2005;21(6):1821-8.

21. Ministério da Saúde (BR). Portaria n 399, de 22 de fevereiro de 2006. Divulga o Pacto pela Saúde 2006 Consolidação do SUS e aprova as Diretrizes Operacionais do Referido Pacto. [acesso 25 mar 2006]. Disponível em http://dtr2001.saude.gov.br/sas/PORTARIAS/Port2006/ GM/GM-399.htm

22. Guedes HM, Paula LD, Nakatani AY, Coelho AB. Resultados alcançados com a estratégia saúde da família após cinco anos de implantação em uma cidade do interior de Minas Gerais. Rev Min Enferm. 2007;11(4):363-8.

23. Ermel RC, Fracolli LA. O trabalho das enfermeiras no Programa de Saúde da Família em Marília/SP. Rev Esc Enferm USP. 2006;40(4):533-9.

24. Ribeiro EM, Pires D, Blank VLG. A teorização sobre processo de trabalho em saúde como instrumental para análise do trabalho no Programa Saúde da Família. Cad Saúde Pública. 2004; 20(2):438-46.
Received: Oct. $3^{\text {th }} 2011$ Accepted: May $7^{\text {th }} 2012$ 